\title{
A funerary perspective on Bell Beaker period in the Western Mediterranean. Reading the social context of individual burials at La Vital (Gandía, Valencia)
}

\author{
Una perspectiva funeraria sobre el periodo campaniforme en el Mediterráneo occidental. \\ Leyendo el contexto social de los enterramientos individuales de La Vital (Gandía, Valencia)
}

\author{
Oreto García Puchol (*) \\ Joan Bernabeu Aubán (*) \\ Yolanda Carrión Marco (*) \\ Lluís Molina Balaguer (*) \\ Guillem Pérez Jordà (*) \\ Magdalena Gómez Puche (*)
}

\begin{abstract}
The discussion about social dynamics in recent Prehistory is supported by the study of funerary practices. The presence and significance of individual and collective burials in Final Neolithic/Chalcolithic societies in the southeast of the Iberian Peninsula provides new evidence for the debate concerning the emergence of social inequalities in this region. Our contribution is based on the recent discovery and excavation of several individual pit burials in domestic contexts at the site of La Vital (Gandía, Valencia). The particularities of the identified burials (different ritual episodes) and their content (Bell Beaker pottery, metal objects, animal offerings) together with an accurate chronometric database allow us to consider several issues in relation to settlement dynamics, social networks and relationships for the period from the end of the $4^{\text {th }}$ to the middle of the $3^{\text {rd }}$ millennium cal $\mathrm{BC}$ in the central area of the Mediterranean coast of the Iberian Peninsula.
\end{abstract}

(*) Departament de Prehistòria i Arqueologia. Universitat de València. Av. Blasco Ibáñez 28. 46010 Valencia, Spain. E-mail: oreto.garcia@uv.es; juan.bernabeu@uv.es; yolanda.carrion@uv.es; 1luis.Molina@uv.es; guillem.perez@uv.es; magdalena.gomez@uv.es

Received 25-VII-2012; accepted 2-XI-2012.

\section{RESUMEN}

La reflexión sobre la dinámica de las relaciones sociales en la Prehistoria reciente encuentra un apoyo clave en el análisis de las prácticas funerarias. La presencia y significación de los enterramientos individuales y colectivos en las sociedades del Neolitico final/ Calcolitico en el sureste de la Península Ibérica proporciona una nueva evidencia al debate sobre la aparición de las desigualdades sociales en la región. Nuestra contribución se basa en el reciente descubrimiento y excavación de varias tumbas individuales en fosa, localizadas en contextos domésticos, en el yacimiento de La Vital (Gandía, Valencia). Las peculiaridades del continente (detección de episodios rituales particulares en las distintas tumbas) y del contenido (vasos campaniformes, objetos metálicos, ofrendas animales), unido a una ajustada cronometría, permiten plantear diversas alternativas relativas a la dinámica poblacional, las redes de circulación de información y las formas de reproducción social entre finales del IV y el desarrollo del III milenio cal BC en el área central del Mediterráneo en la Península Ibérica.

Key words: Chalcolithic; Bell Beaker; Funerary practices; Social relationships; Metal working; Southeast of Iberian Peninsula.

Palabras clave: Calcolitico; Campaniforme; Prácticas funerarias; Relaciones sociales; Metalurgia; Sureste de la Península Ibérica. 


\section{PRESENTATION}

The Bell Beaker phenomenon provides an ideal framework within which to study social relationships during the $3^{\text {rd }}$ millennium cal $\mathrm{BC}$ on a European scale. During earlier research the debate was centred on discussing hypotheses about its genesis, adopting a diffusionist perspective to explain its expansion (Castillo 1928). However, from the 1960's onwards, new explanatory models were adopted which stressed the special significance of associations (Bell Beaker ware, archer equipment, ornaments) within funerary contexts. The focus shifted towards the interpretation of Bell Beaker grave goods as prestige elements associated with the dominant elite (Clarke 1976). Within the context of new relationships, which linked the con-

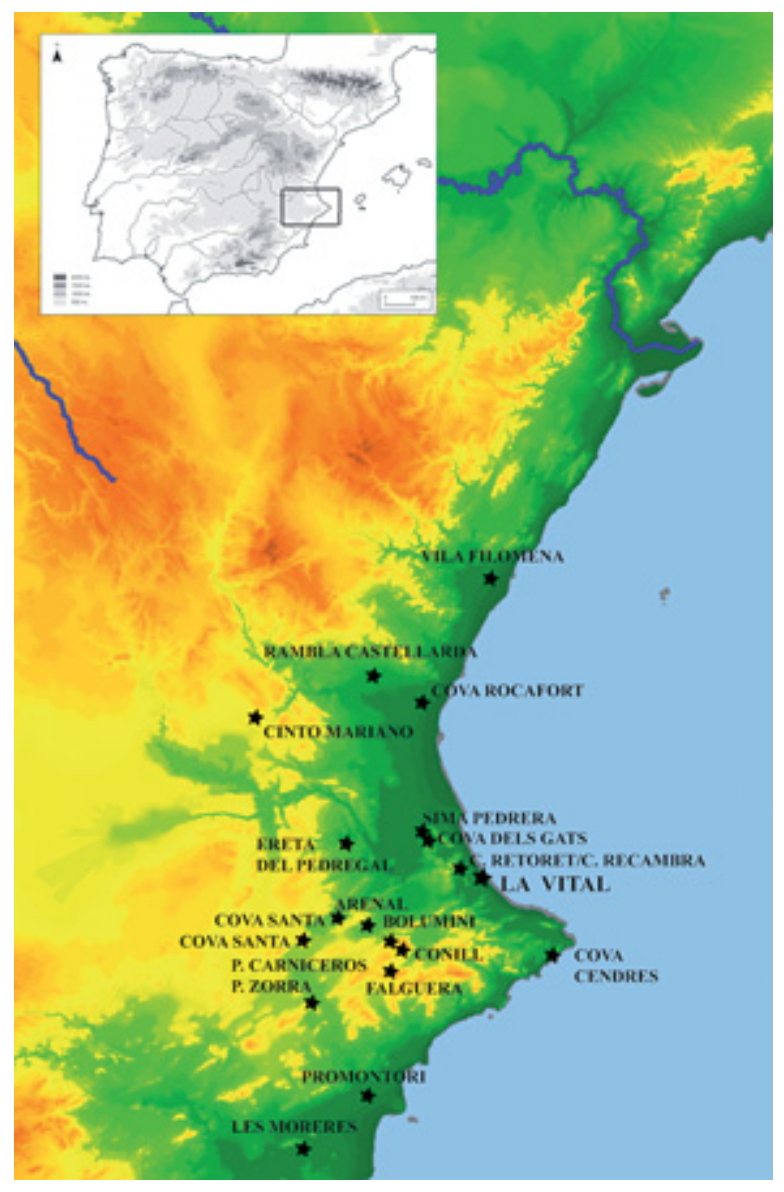

Fig. 1. Location of La Vital and the main Bell Beaker sites in the Valencian area. MDT from PNOA (design by A. Díez). centration of power with economic transformations (accumulation of surplus as a consequence of the secondary product revolution/metallurgy/ development of trade networks), the associated Beaker grave goods encoded the achievement and prestige of individuals or families (Clarke 1976). At present, the most prominent hypothesis, associates the Beaker phenomenon with particular rites and symbolism of the elites which were transmitted through established social networks (Sherratt 1987; Garrido Pena 2005). However the debate remains open. Rites are criticised and their diffusion could also be seen in relation to other population factors such as seasonal movements, marriage, etc. (Case 1995; Brodie 1997).

In this paper we present a unique burial ritual practiced at the Chalcolithic settlement of La Vital (Gandía, Valencia, Spain) (Fig. 1). Recent excavations at the site have documented individual pit burials which were integrated into the living space, and were associated with grave goods and offering which amongst others included Beaker wares, weapons and other metal items, ornaments and animal remains. We discuss funerary behaviour from the point of view of social relations during the Chalcolithic in eastern Spain, and interpret its significance within a broader European approach.

\section{BACKGROUND}

Within the framework of assessing long term socio-ecological dynamics in the prehistory of the western Mediterranean region, two research teams from the University of Valencia (Spain) and Arizona State University (USA) carried out archaeological survey and systematic excavation in the central Valencian region (Barton et al. 2004). The main goal was to investigate the Neolithic transition and the development of agricultural economies and their effect on social dynamics (Bernabeu et al. 2006; García Puchol and Aura 2006; Bernabeu and Molina 2009; García Puchol et al. 2009; Barton et al. 2010). In this context different sites were excavated that cover the Neolithic and Chalcolithic periods. One of these sites is La Vital, a settlement located on the terraces of the Serpis River, on its right bank as it crosses the coastal municipality of Gandía (Valencia, Spain). 
Rescue excavations were carried out in 2005 and 2006 by a research team from the University of Valencia (Spain) while J. Pascual Beneyto excavated the eastern sector of the site (Pérez Jordà et al. 2011). Data from both sectors are included in this paper.

A series of occupation phases were identified, including structures dated to the Epicardial Neolithic, Chalcolithic, Iberian, Roman and Islamic periods. The majority of the features though relate to a metallurgical settlement of pre-Bell Beaker and Bell Beaker Chalcolithic age (2800-2300 cal BC) (Pérez Jordá et al. 2011). The structures, which were all preserved as negative marks on the ground, have been identified as cuvettes, storage pits, a ditch, domestic spaces and individual burials. Using K-means Cluster analysis (Gómez et al. 2011) on the basis of spatial criteria (x, $\mathrm{y}$, dispersion), we consider the presence of 10 groups of structures (Fig. 2). Except groups 4 and 10 (formed by a single structure), all other groups comprise structures that could be interpreted as houses, working spaces and pits, and in some cases burials. This research project has produced excellent results. These allow us to observe with chronological precision (based on AMS dates on human remains or other short-life elements), the appearance of metallurgy and the Bell Beaker in the central-southern Mediterranean coast of the Iberian Peninsula (Tab. 1, Fig. 1 and Fig. 2).

According with the Sumprob of the 12 dates obtained, the time-span of La Vital Chalcolithic site occurs between $2836-2337$ at $1 \sigma$ or 2886 2280 at $2 \sigma$ level (Tab. 1). Material culture (flint industry, ceramic collection) is quite similar to that from other sites dated to the second half of the $4^{\text {th }}$ millennium cal BC. The only difference is the evidence for metalworking dated from the very beginning of the sequence. Processing of copper is indicated by the presence of melted metal droplets and ceramic reduction vessels. The two dates of Bell Beaker burial are statistically the same, and produce and average of 2456-2289 at $1 \sigma$, or $2464-2209$ at $2 \sigma$ level. That is, the end of the site coincides with the end of Bell Beaker pottery. At this time only Maritime Herringbone Variety (MHV) and corded-zoned Maritime variety $(\mathrm{CZM})$ vessels are present. These Beakers were exclusively associated with burials and absent from domestic contexts. La Vital was abandoned before regional Beaker styles developed.

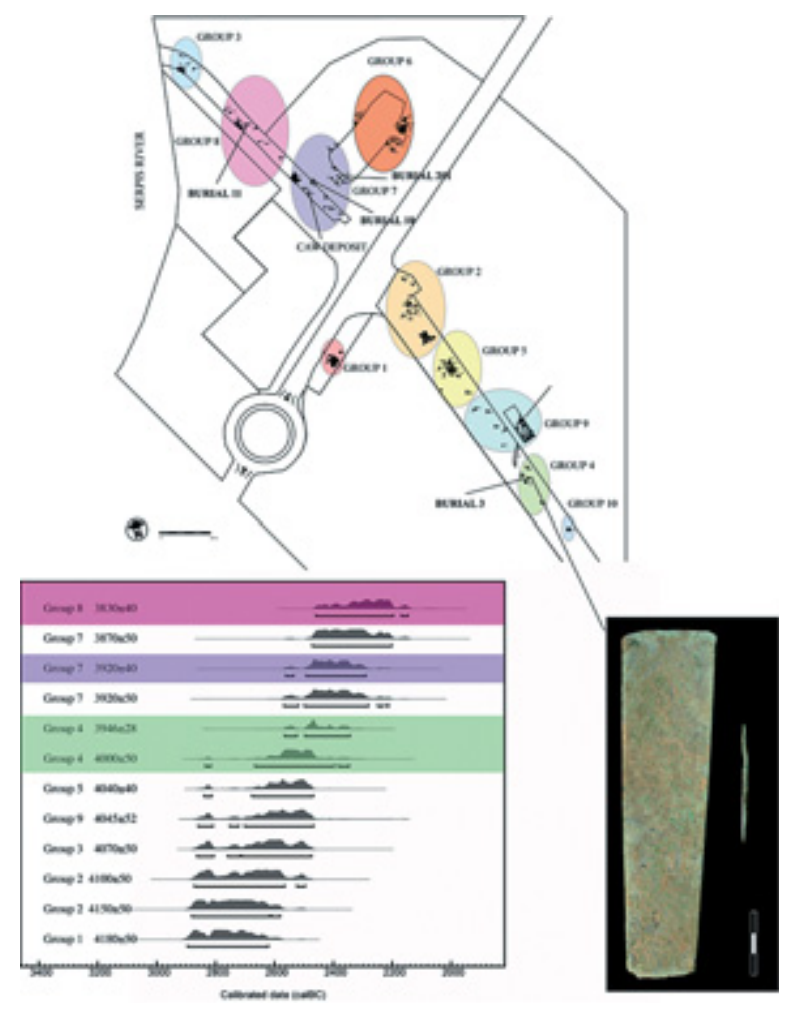

Fig. 2. Plan of La Vital (Gandía, Valencia). Burial 3 has a flat copper axe and a bipointed awl. AMS dates calibrated using Oxcal v4 1.7 (Bronk Ramsey 2009) and the IntCa109 curve (Reimer et al. 2009) (see Tab. 1).

La Vital, together with Ereta del Pedregal (Juan Cabanilles 2009), located to the North near the Júcar River, is the only settlement where metalworking is clearly documented prior the Bell Beaker phase. Isotopic analysis indicates that at La Vital, metals reached the settlement from the south (Almería) through maritime routes (Molina and Orozco 2011; Rovira and Montero 2011).

In the interior of the region (Serpis River valley), metallurgical activities in settlements such as Jovades and Niuet with long sequences beginning during the second half of the $4^{\text {th }}$ millennium cal $\mathrm{BC}$, are largely unknown or very rare. In contrast, metal objects are more common in collective burials in caves. If the production and consumption of metal objects was different, as their variable presence at different sites infers, we may suggest that metals would have played a key role in accelerating the new social dynamics that relay in the individual burials, but not in collective ones. 


\begin{tabular}{|c|c|c|c|c|c|}
\hline Sample ID & Laboratory & Material & AGE BP & Cal BC 68.2 & Cal BC 95.4 \\
\hline UE 3110 BB Burial & Beta 222443 & Human bone & $3830 \pm 40$ & $2391-2202$ & $2460-2146$ \\
\hline UE 2214 Burial & Beta 222444 & Human bone & $4000 \pm 50$ & $2574-2470$ & $2836-2346$ \\
\hline UE 2214 Burial & OxA-V-2360-15 & Human bone & $3946 \pm 28$ & $2550-2350$ & $2566-2344$ \\
\hline UE 2202 House & Beta 222445 & Ovis aries & $4040 \pm 40$ & $2620-2488$ & $2840-2468$ \\
\hline UE 3088 House & Beta 222446 & Bos taurus & $3920 \pm 40$ & $2472-2346$ & $2562-2290$ \\
\hline UE 3053 House & Beta 222447 & Bos taurus & $3870 \pm 50$ & $2458-2290$ & $2472-2202$ \\
\hline UE 3056 BB Burial & Beta 229791 & Human bone & $3920 \pm 50$ & $2474-2310$ & $2568-2212$ \\
\hline UE 2137 Heart & Beta 229792 & Ovis aries & $4100 \pm 50$ & $2855-2577$ & $2872-2496$ \\
\hline UE 2194 House & Beta 229793 & Bos taurus & $4150 \pm 50$ & $2872-2638$ & $2881-2580$ \\
\hline UE 2115 Pit & Beta 229794 & Sus sp. & $4180 \pm 40$ & $2880-2680$ & $2890-2630$ \\
\hline UE 3144 House & Beta 229795 & Sus dom. & $4070 \pm 50$ & $2840-2494$ & $2864-2474$ \\
\hline UE 2193 Ditch & AA 72170 & Bos taurus & $4045 \pm 52$ & $2831-2480$ & $2860-2467$ \\
\hline \multirow[t]{6}{*}{ Sumprob } & 1 sigma & 0,0458 & & $2836-2815$ & \\
\hline & relative area & 0,9268 & & $2671-2337$ & \\
\hline & & 0,0273 & & $2322-2308$ & \\
\hline & 2 sigma & 0,9758 & & & $2876-2280$ \\
\hline & & 0,0175 & & & $2250-2230$ \\
\hline & & 0,0065 & & & $2219-2211$ \\
\hline \multirow[t]{7}{*}{ B. Beaker Average } & 1 sigma & 0,2525 & & $2456-2418$ & \\
\hline & & 0,2301 & & $2407-2376$ & \\
\hline & & 0,0110 & & $2366-2365$ & \\
\hline & & 0,5056 & & $2351-2289$ & \\
\hline & 2 sigma & 0,9103 & & & $2464-2277$ \\
\hline & & 0,0634 & & & $2252-2228$ \\
\hline & & 0,0261 & & & $2222-2209$ \\
\hline
\end{tabular}

Tab. 1. AMS dates from La Vital (Gandía, Valencia) calibrated using the Oxcal v4.1.7 (Bronk Ramsey 2009) and the IntCal09 curve (Reimer et al. 2009).

\section{TOMBS AND RITUALS}

Excavations at the settlement provide information on 4 individual burials, which were either primary or secondary interments. Of these, two were male, a single female and the fourth of unidentified sex (Roca de Togores 2011). The burials were in pits of variable size and morphology and were dispersed across the site, suggesting some association with different domestic groups of structures. Although these pits probably were not excavated for that particular purpose, they show evidences of reconditioning works and/or a process of filling that follows some particular ritual conditions. In continuation, we present the characteristics of the burial pits and their content.
Burial 3 was contained within a medium size pit (3230L) of bell-shaped profile and flat base (Fig. 3). On the northern side of the pit and from the level of the base, a lateral chamber of $1.5 \mathrm{~m}$ long and $0.65 \mathrm{~m}$ deep and high was excavated. Within this, the partial remains of an individual and various grave goods were deposited. The chamber was sealed with medium size pebbles and then was completely filled with earth. The human remains, corresponding to a male individual between 20 and 30 years of age, consisted of a deteriorated and fragmented skull, the mandible and various fragments of the postcranial skeleton, including pieces of tibia. These few bone remains were dispersed and lay at the base of the structure (Fig. 3). The skull was more or less central, 


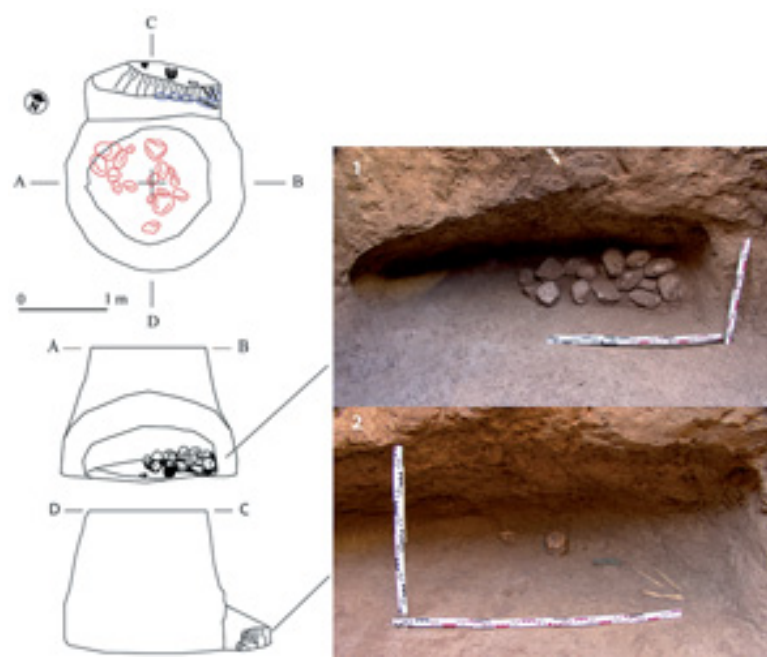

Fig. 3. La Vital: Burial 3 was contained within a medium size pit (3230L) of bell-shaped profile and flat base. Picture 1, lateral chamber sealed with medium size pebbles. Picture 2, View of skull, various fragments of the postcranial skeleton, a flat copper axe and a bipointed copper awl at the base of the structure.

with the mandible to the left and to the right a flat copper axe (dimensions: $165.4 \mathrm{x} 45.5 / 32.1 \mathrm{x}$ $7.6 \mathrm{~mm}$; weight: $304.7 \mathrm{~g}$ ) and a bipointed copper awl of square section (dimensions: 52.6 × $2.7 \times$ $2.2 \mathrm{~mm}$; weight: $1.6 \mathrm{~g}$ ). The postcranial remains were located in the western end of the chamber. Two AMS dates on samples of the skeletal remains (Beta-222444 and OxAV236015) place the context within the mid $3^{\text {rd }}$ millennium cal BC (Tab. 1).

Burial 10 is another large pit structure $(9354 \mathrm{~L})$ with a truncated cone profile and a flat base (Fig. 4). As in the case of Burial 3, there was significant effort invested in the preparation of the interior of the pit. Similarly, the associated grave goods and significantly the specific character of the observed ritual, reflect special treatment of the dead, in this case a female of approximately 20 to 25 years of age (Fig. 4).

The funerary ritual appears to have been carried out as successive episodes, presumably over a relatively short period of time (Fig. 4). Initially, small vessels were placed bottom up at the base of the pit. The interior of the vessels and the surrounding deposits contained the remains of up to 8 rabbits, suggesting food offerings. The vessels were surrounded by a small stonewall resting on the pit wall. Overlying this, a $60 \mathrm{~cm}$ thick layer of

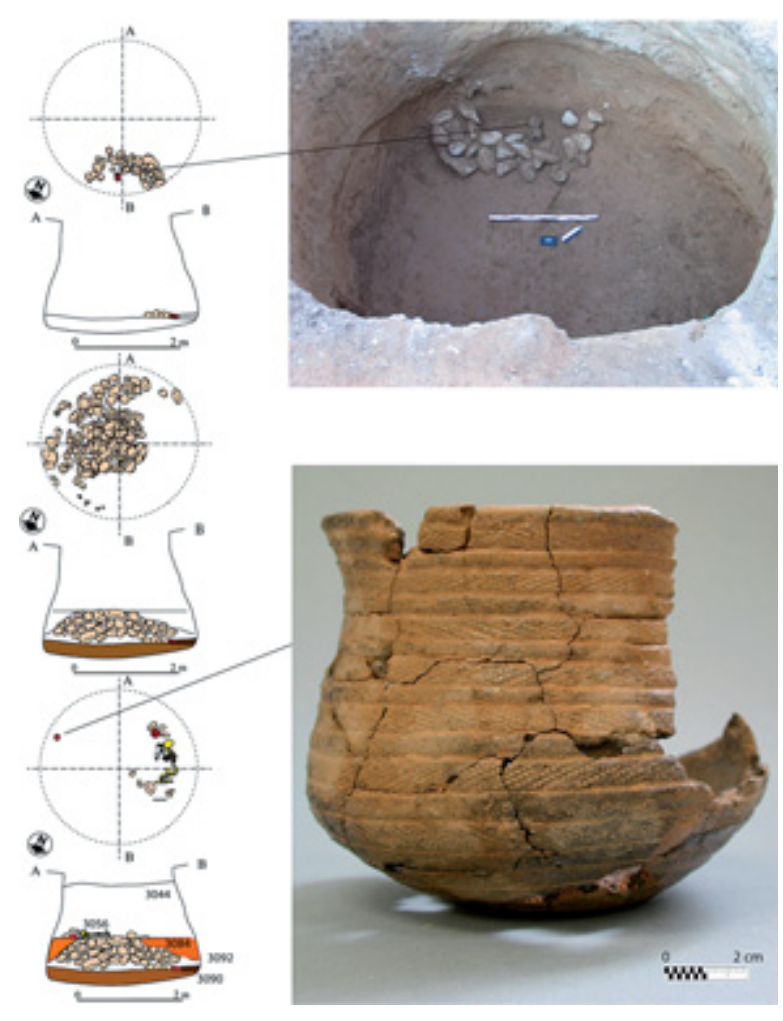

Fig. 4. La Vital (Gandía, Valencia): succesive episodes of Burial 10, corresponding to a female individual. Image of the upper sections with small vessels placed bottom up the base, surrounded by a small stonewall resting on the pit wall. On the other side of the structure a Maritime Bell Beaker (Herringbone Variety) was placed.

stones and earth formed a horizontal base. On this was laid the body of the young woman, who was placed along the western edge of the pit, flexed in a right lateral lying position. The skeleton was uncovered almost complete. A small cooking pot (0.841) was placed on one side of the skull and between two stones stuck in the ground. On the other side of the structure a MHV vessel (0.51) was placed (Fig. 4). All these were covered by sand, which was overlain by a thick layer of brownish clay that filled the structure. The study of the recovered materials allows us to conclude that filling of the structure took place over a short period of time. The presence of fragments of a range of pottery vessels within the fill, both above and below the body suggests a single episode linked to a burial ritual during which some liquid (?) may have been drunk (Fig. 5). According to an AMS date on a sample of the skeletal remains (Beta- 


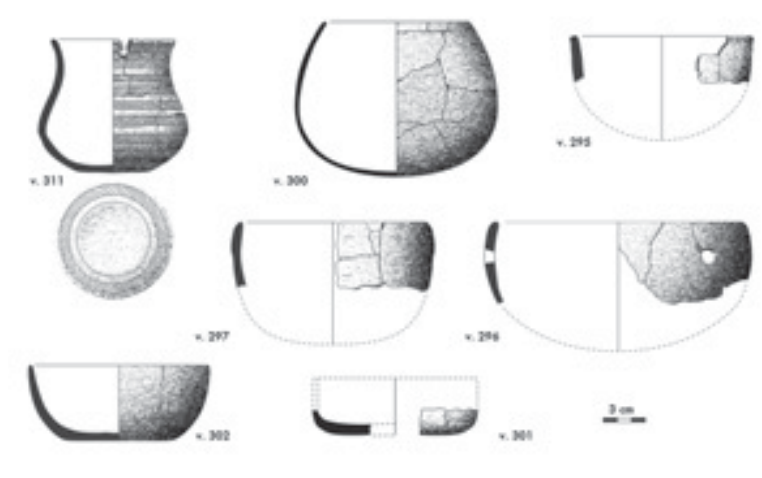

Fig. 5. La Vital: Pottery vessels placed in burial 10 .

229791), the event took place between 2474 and 2310 cal BC (1 $\sigma$ probability).

Burial 11 was contained within a medium size pit (2074 L) with a bell-shaped profile and flat base (Fig. 6). On top of a horizontal layer was placed a male individual of between 20 and 40 years of age, lying in a flexed right lateral position. The skeleton was almost complete except for the largest part of the skull. Only a few small cranial bones were recovered and 6 teeth. On the basis of this evidence, we suggest that this was a primary interment and that at a later stage the skull was removed. Next to the body was placed a corded-zoned Maritime variety (CZM) vessel, along with other grave goods including a copper dagger (dimensions: $72.1 \times 24.5 \times 1.8 \mathrm{~mm}$; weight: $16.85 \mathrm{~g}$ ), an arciform pendant (Semicassis undulata) and a flint arrowhead (Fig. 7). After placement of the body, the structure was filled with medium size stone blocks and earth. The burial produced a radiocarbon date of 2389-2202 cal BC (1 o probability Beta-222443).

Burial 201 was only partially preserved and therefore only a rough description of its characteristics and nature is possible (Pascual Beneyto et al. 2008). As in all previous cases it was a pit structure, probably with a circular truncated cone profile and a flat base. At the bottom were found two cranial fragments of an individual of undetermined sex. Immediately next to these were recovered 9 green stone-beads, a copper tanged dagger and fragments of a carinated bowl with incised decoration (Fig. 8). This was covered by large pebbles and soil, and was overlain by a fill that sealed the structure. No radiocarbon dates are
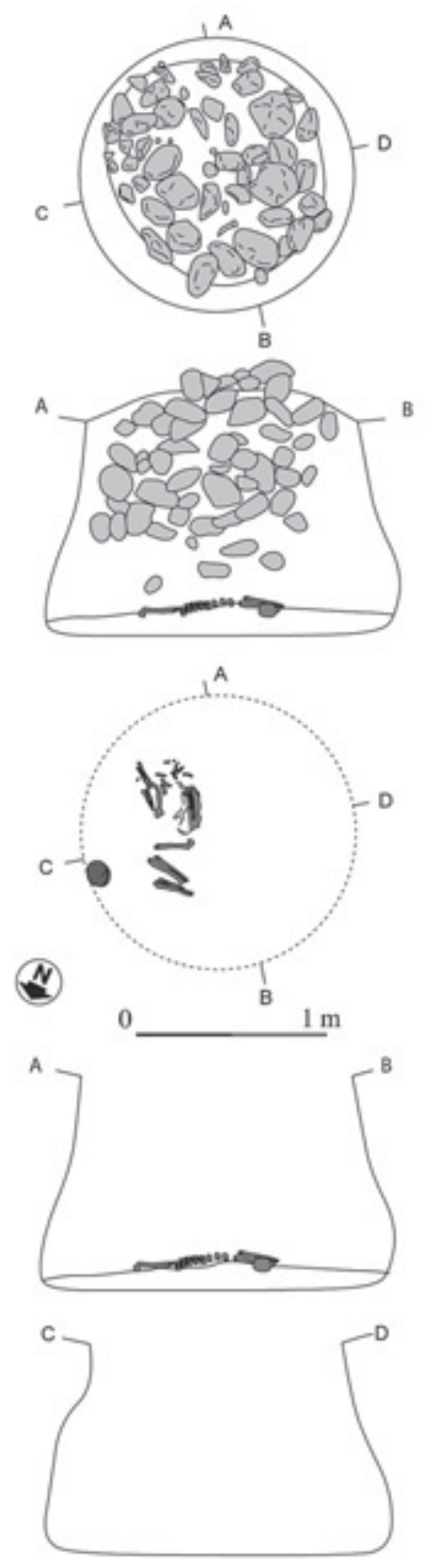

Fig. 6. La Vital (Gandía, Valencia): Burial 11 corresponds to a male individual almost complete, except for the largest part of the skull, on top of a horizontal layer.

available for this burial, although the grave goods and especially the copper tanged dagger are very similar to those found in Burial 11, pointing to a similar chronology.

The burial evidences described above reflect a series of distinctive funerary rituals, which point 


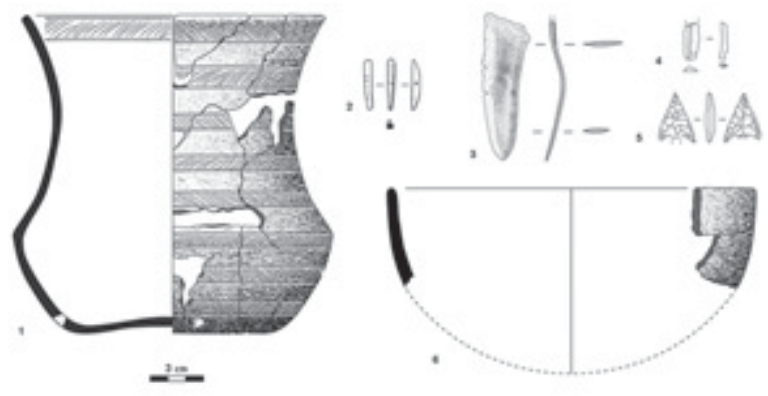

Fig. 7. La Vital (Gandía, Valencia). Grave goods found in Burial 11. 1: Maritime Bell Beaker (corded-zoned variety), 2: Arciform pendant (Semicassis undulata), 3: Copper dagger, 4: Bladelet, 5: Flint arrowhead, 7: Pottery vessel.

to an underlying complex symbolic framework. All burials were individual interments in the interior of the settlement and were associated with diverse domestic units (Fig. 2). Only one of these units included 2 burials: 10 and 201. Burial 10 was the most elaborate and contained the remains of a young female. It may also be significant that near to this burial was a pit in which a complete anatomically associated bovid had been placed (Fig. 9). No pathology, that could explain the event, was identified, so relation between this and Burial 10 cannot be excluded. The practice of animal burials is not new, and there are examples both from Iberia (Cámara et al. 2008) and the rest of Europe (Healy and Harding 2004). In Burial 11 a male individual was accompanied by characteristic weapon equipment. A peculiarity of this interment was that apart from some teeth, the rest of the skull was missing. In contrast, in burial 3 it was mainly cranial elements,

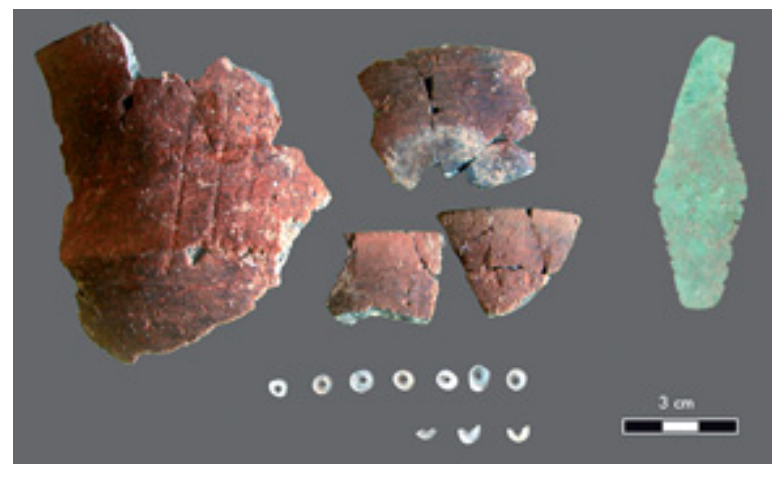

Fig. 8. La Vital (Gandía, Valencia). Grave goods found in Burial 201: green stone-beads, copper tanged dagger and fragments of an incised carinated bowl. which had been deposited, with only a few postcranial fragments present. The presence of human remains scattered in no funerary structures (including a complete mandible in the fill of a habitation structure) may imply some type of post-mortem practices. Similar treatment of the dead is not new in the regional context. In fact, similar practices have been documented within diverse societies of the western European Neolithic (Guilaine and Zammit 2001), thus exposing the complex relations that these groups established with the world of the dead.

The presence of Bell Beaker vessels is symptomatic (one in Burial 10 and another in Burial 11 ) and is only linked with funerary contexts. Both vessels are of impressed varieties (Harrison 1977). This fact highlights the importance of these types over the incised-stamped varieties that define the regional style (Bernabeu 1984). The first vessel (Burial 10) is of typical MHV decoration made with the use of a bone/wood comb. The second (Burial 11) represents one of the few cases of CZM in the Levantine area (Vil.la Filomena, Harrison 1977; Bernabeu 1984), and is one of the southernmost examples of this kind of decoration in Europe so far. Parallels must be searched in Catalonia and southern France (Salanova 2005; Lemercier 2011), where vessels with this particular decoration and shape (a carinated profile with a long rim; the angularity in the lower part of the body, and a dished omphalos base) are quite common. It should be noted that although made with local clay, Bell Beakers are the only pots in the site that not include temper (Molina and Clop 2011).

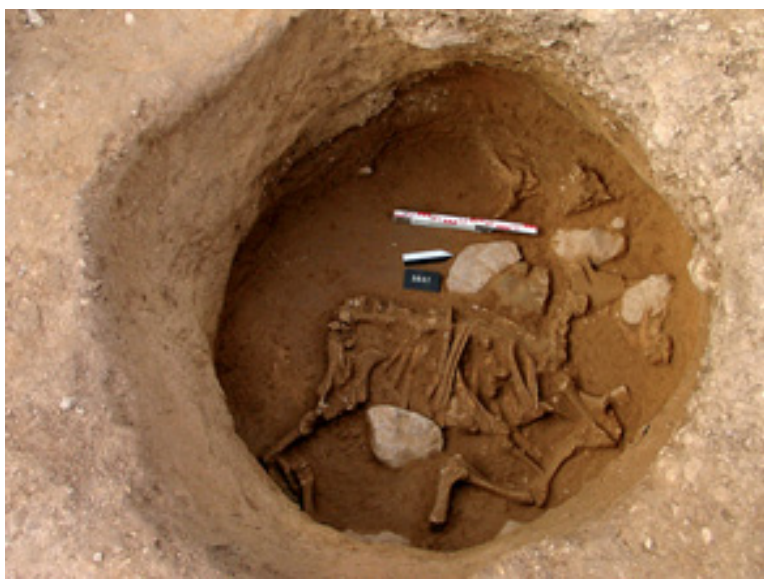

Fig. 9. La Vital (Gandía, Valencia). Complete anatomically bovid placed in a pit near Burial 10 . 


\section{BELL BEAKER FUNERARY RITUALS IN THE SOUTHEAST IBERIA CONTEXT}

The Bell Beaker funerary phenomenon expands over a significant part of Europe during the $3^{\text {rd }}$ millennium cal BC. Certainly, different practices and the survival of regional funerary traditions that coexist with the symbolism of the Bell Beaker package may be recognized. In fact, the use of individual and collective burials (pits, barrows, megalithic tombs, natural caves) shows the persistence of ancestral traditions introducing the new ideological message associated with the Bell Beaker culture. Thomas (2005) points out differences in the presence of individual burials between regions and suggests a direct connection with the existence of individual practices during the Late Neolithic. Individual tombs are pre-eminent for example in Britain, but in adjacent areas, such as Ireland and France they are rare. In southern France only 10\% of Bell Beaker tombs are individual (Lemercier 2011). We can observe a similar situation in Iberia where individual Bell Beaker tombs are scarce. They are quite common in the Meseta region (Ciempozuelos) (Garrido et al. 2005) but sporadic in Catalonia (Clop 2005) and the Valencian region (Juan Cabanilles 2005). At the same time, megalithic burials and artificial caves for collective interments are characteristic in other regions of the Iberian Peninsula (e.g. tholoi of Los Millares, Almería, Cámara and Molina 2006; Chapman 2008).

In fact, the transition from collective burial practices to those in which individuality prevailed (Garrido-Pena 2005) cannot be interpreted absolutely (Bueno et al. 2005; Liesau et al. 2008). There are significant examples of the use of old collective tombs, and in several cases -the megalithic tombs of La Sima, in Soria (Garrido et al. 2005), and Tres Montes, in Navarra (Andrés et al. 2001) this use is related with special closing ceremonies associated with Bell Beaker deposits.

As in other regions of Europe, individual burials at La Vital form part of a tradition with direct precedents in previous periods (Bernabeu 2010). Individual burials are documented in the Iberian Peninsula at least from the end of $6^{\text {th }}$ millennium cal BC, as is the case of Los Cascajos and Paternanbidea, Navarra (García Gazólaz 2007; García Gazólaz and Sesma 2007). At this time we know few examples of burials in caves as Chaves (Utrilla et al. 2008), Can Sadurní (Blasco et al. 2011),
Sarsa (García Borja et al. 2011), Caldeirão (Zilhão 1992), but it is very difficult to prove if these were individual or collective tombs. Open air burials, forming isolated necropolises (Sepulcros de Fosa), are quite common in the $5^{\text {th }}$ millennium cal BC, when we yet know the appearance of the first caves exclusively used for funerary purposes in the East as Sant Martí (Torregrosa and López 2004) and the Megalithic tombs of western Iberia.

Immediately prior to the pre-Bell Beaker period and contemporary with the start of the settlement at La Vital are the pit burials in the adjacent site of Beniteixir. In this case though, no metal objects or evidence for metallurgy was noted (Pascual Beneyto 2010), suggesting an important difference compared to La Vital over a relatively short time interval. Late Neolithic individual burials are also known from El Garcel (Almería), Palas (Lorca, Murcia) (Márquez 2004) and Costamar (Castellón) (Flors 2009). In the regional literature there are only a few other references to individual Bell Beaker burials (Vil.la Filomena, Lloma de 1'Atarcó) with hardly any confirmed contextual information available (Bernabeu 1984).

Leaving aside the specifics of the treatment of the dead as described above, what stands out is the low proportion of burials compared to the number of excavated structures (4/115). This suggests that only a small number of individuals received such specific treatment, although they would not have been the only segment of the population subject to some kind of funerary ritual. During the same period in the region of Valencia, caves located outside settlements were used as funerary deposits for collective burial, implying a duality with a long tradition in the region (Soler 2002; McClure et al. 2011). Several examples with well-preserved Bell Beaker grave goods exist, such as Sima de la Pedrera, Cova dels Gats or Cova Santa de Vallada (Bernabeu 1984; Juan Cabanilles 2005).

The content of individual Bell Beaker tombs is variable and may include one or various elements or even none, as the Arenal site case reveals. Dated to 2203-1973 cal BC (Beta-228894, Diez Castillo 2011), the settlement included individual pit tombs with no grave goods or any indication of specific rituals. Moreover, the collective burials of the Late Neolithic, even in cases where there is hardly any information about the associations, include anthropomorphic figurines, large flint blades, arrowheads and daggers made with bifa- 
cial retouch, bone tools, ornaments and pottery. Some of these items were made of exotic raw materials (green stone, amber, and some specific types of flint), and could have been manufactured by part-time specialists. During this period pottery would not have been a special grave good.

Concluding, the most evident difference between pre-Bell Beaker and Bell Beaker grave goods comes from: a) The generalization of the military panoply, with copper daggers, axes, and arrowheads (palmela). If we generalize on the basis of the data from La Vital where only the female burial lacked weapons, we may suggest a relationship between military panoply and an emphasis on the role that male individuals played in the society (Salanova 2005; Lemercier 2011); b) An increase in the volume of exotic items, including those made of ivory, and c) The inclusion of ceramic vessels as special grave goods. The first Bell Beakers, including those of La Vital, are mainly related with funerary contexts.

These factors together with the disappearance of ideological objects in collective burials that were common during the previous period, such as anthropomorphic figurines and eyed-idols, can be interpreted as a change in symbolic beliefs which linked these associations with specific ceremonial practices related to the emergence of elites. At La Vital it is clear that the Beaker vessels are exclusively from funerary contexts and are associated both with male and female individuals. Their presence together with other associations in Burial 10, suggests the existence of some type of ceremonial practices that linked the dead with the world of the living. As pointed out by various authors, the significance of Beaker vessels is related to their symbolism (Sherratt 1987; Thomas 2005). Their presence in different funerary contexts (individual or collective) is related to their ability for spreading along a great territory when this symbolism is linked to particular social dynamics. The deposition of animal remains together with the filling episode of Burial 10 may be related to the special significance of ceremonial feasting in association with funerary rituals, which becomes more and more visible in prehistoric societies.

\section{SOCIAL RELATIONSHIPS IN BELL BEAKER CONTEXT}

The $4^{\text {th }}$ and $3^{\text {rd }}$ millennia $\mathrm{BC}$ is a period of major change throughout the central and southern
Iberian Peninsula. Dramatic population growth, the emergence and development of copper metallurgy and the presence of significant spatial inequalities in the extension of settlements, have been used variably to suggest significant social asymmetries, including hypotheses for the formation of State Societies around the first half of the $3^{\text {rd }}$ millennium BC (Nocete 2001; Cámara and Molina 2006; Nocete et al. 2010). Some of them (Nocete 2001) apply world system theory and suggest that this period illustrates the formation of the first states, connecting wide areas of central and southern Iberia. Within such a framework, La Vital would have been located at the periphery of a region controlled by Los Millares (López Padilla 2006). In this framework copper metallurgy plays a key role.

The study of La Vital indicates that copper and the technology used to manufacture tools were imported from the south (the area near Los Millares), but such interaction is difficult to place within a framework of centre-periphery relationships. It seems clear that copper metallurgy would have played a key role in social dynamics, accelerating some aspects of social behaviour, such as those represented by individuals buried outside the collective tombs. What is less evident is exactly what this means in terms of social relationships. Nonetheless, we believe there is no evidence for economic specialization and interdependence between sites that could explain the existence of a structure of social hierarchy and permanent decision-making at such a large scale (Bernabeu et al. 2012).

In this context, supporters of Chalcolithic State formation, argue that collective funerary practices have been interpreted as the materialization of a parental ideology, the first step in explaining the formation of the earliest social classes. This model assumes that individual burials and adscribed statatus follows the breakdown (during Bell Beaker and Bronze Age) of parental ideology expressed by the collective funerary practices. The Chalcolithic tombs of La Vital coul be interpreted in this way, highlighting the importance of singular rituals of individual tombs from the Bell Beaker period. Nevertheless we have shown that individual burials are a common feature of the whole Neolithic period. Moreover, some of these burials correspond to children with grave goods (Gibaja et al. 2010: 63-64). If we assume that the association of children and grave goods is a good proxy of an

Trab. Prehist., 70, N. ${ }^{\circ}$ 2, julio-diciembre 2013, pp. 264-277, ISSN: 0082-5638

doi: $10.3989 /$ tp.2013.12112 
ascribed status, then we can conclude that neither individual burials nor ascribed status emerge as a result of the breakdown of the parent ideology.

\section{CONCLUSIONS AND DISCUSSION}

The discoveries at the Chalcolithic site of $\mathrm{La}$ Vital allow us to present a general view of the patterns of late prehistoric funerary practices in eastern Iberia, mainly the East (Júcar and Segura areas) and south-east (Murcia and Almería areas). We highlight the significant duality between individual and collective tombs, both in terms of their location (inside or outside of the settlement) and the specifics of their construction and other aspects (tholoi, artificial caves, natural caves).

This duality persisted for a long time and the question is, how can it be explained? Was it the result of distinct networks of social interaction through lineages and families? Or can it be better understood as the manifestation of funerary practices of different but neighboring groups?

There is no convincing explanation for this phenomenon, and it is difficult to interpret the observed differences that suggest social relations more complex and diverse than usually accepted. For example, in the case of La Vital, caves with multiple burials along with pre and Bell Beaker pottery are common. At the same time in nearby settlements, individual burials with grave offerings are present. The distribution of these offerings in both types of burial does not suggest differences in wealth accumulation. The general dynamics of the $4^{\text {th }}$ and $3^{\text {rd }}$ millennia $\mathrm{BC}$ affected the social spaces represented by collective and individual burials, eventually favoring the predominance of the former. The grave offerings, metal, Bell Beaker and ivory objects, suggest that certain individuals accumulated (and redistributed?) goods that had originated from interregional exchanges. Moreover, the predominance of weapons amongst these objects suggests that their position was supported by an ideology in which the strength exhibiticion has some social value.

Nonetheless, funerary rites are only part of the record. In order to fully evaluate social change we need to correlate rites with other social and economic manifestations. For this it is necessary to correctly situate the archaeological evidence in time and space. Despite the latest advances, there are still not enough dates to allow for time comparison between sub-regions. To the south the majority of the dates are from only a few sites and most were obtained on wood charcoal. To the north there are more sites with dates, mainly obtained from short-lived material such as bones or seeds. Howewer, we know that the eastern and southeastern parts of Iberia were already connected within exchange networks from the beginning of the Neolithic. The earliest manifestation of these, the schist bracelets of the $6^{\text {th }}$ millennium cal $\mathrm{BC}$, were soon followed by polished stone artefacts made of the same raw material during the $4^{\text {th }}$ and $3^{\text {rd }}$ millennia cal BC. In certain cases finished objects circulated while in others, raw materials were exchanged. In any case and as far as we know, the direction of flow was always from south to north. Metal and Metalwork knowledge, as evidenced by La Vital, is not an exception.

The above evidence suggests that these parts of Iberia formed a densely interlinked system, within which raw materials, finished objects, information and probably people circulated. The nature, scale and intensity of this network was variable, occasionally extending beyond the geographical areas mentioned above. Thus, for example, the distribution of the eye idols (Hurtado 2008) reveals the existence of extended interregional networks through which information circulated. At a later stage, these networks enabled the circulation of ivory (Schuhmacher et al. 2009) and the first Bell Beaker ware, while at the same time linking the region within the broader Mediterranean context. At a more restricted scale, different studies highlight the circulation of raw materials and/or finished objects that became important at the regional scale, such as the variscite of Pico Centeno (Odriozola et al. 2010), or the distribution of some hard stones along the eastern façade of Iberia (Orozco 2000).

All the above reflect a common situation, the superimposing of exchange networks. Different types of raw materials were moved within the same physical territory (variscite, ivory, hard stones, metals). Occasionally this flow included more subtle elements such as information associated with technologies such as metallurgy, or ideology such as the eye motifs or the first Bell Beaker ware that followed, and which expanded the network. Exchange of information would have taken place alongside the movement of raw ma- 
terials, but it affected different parts of the territory that it passed through. Moreover, the flow of information was dynamic and therefore subject to change through time. For this reason it is difficult to explain the kinds of information exchanged and its evolution through time. Interaction among diversified agents would have taken place, thus forming a dynamic network. This in turn would have affected the territory and would have been influenced by the ways in which the diverse agents occupied and organized it. For this reason we assume that social processes taking place in one part of the territory would have affected other parts, as has already been shown (López Padilla 2006), but this is not to assume the existence of states and the center-periphey relationships.

Despite the fact that evidence for interaction and contacts between groups may be recognized, an in-depth understanding of their reach is still elusive. Recent discussion of the issue (Bernabeu et al. 2012) has provided a view of long-term historical dynamics from the perspective of complex systems. Different modes of 'estimating' the level of complexity within which past social interactions at different scales took place are put forward. The frequency and intensity of interactions may be a good indicator of the level of complexity. One of the main characteristics of complex systems is the way they develop or evolve by merging previously independent subsystems, which become progressively interrelated. Such a relationship takes the form of diverse hierarchical organization (functional, of information, decision-making, etc) that consequently appears in very different domains and follows variable patterns. What is important is to be able to 'estimate' the degree of interdependence amongst the groups that form the system.

Communities can be largely or completely autonomous. They can be loosely coupled by ideology, kinship, or social ties, for example. They can be tightly interdependent, relying on each other economically and politically. If we consider that the entire southern and southeastern part of Iberia functioned as a world system, we may expect to identify archaeological manifestations of the mechanisms which facilitated the transmission of information and decision-making by permanent hierarchies. In these sense, the variability observed in funerary rites provides an additional tool for an in-depth study of these dynamics. Normalization of the treatment of the dead, or in the associated grave goods could be aspects that may indicate the existence of the mechanisms mentioned above. However, these are not easily detected until at least the Bronze Age, although it is true that data is scarce and that little effort has been expended in enriching the record.

\section{ACKNOWLEDGEMENTS}

The rescue excavation at La Vital was conducted by the Departament de Prehistòria i Arqueologia of Universitat de València, Spain (Guillem Pérez Jordà and Joan Bernabeu Aubán dirs.). Oreto García Puchol is a researcher of Ramón y Cajal Research Program. Guillem Pérez Jordà has worked until march 2013 in the L. Arqueobotánica, Instituto de Historia, Centro de Ciencias Humanas y Sociales, Consejo Superior de Investigaciones Científicas (Madrid). We are grateful to Josep Pascual Beneyto for providing dates for the burial 201. We are also grateful to all the members of La Vital research team (María Pilar Carmona, Xavier Clop, Agustín Diez, Maria Fontanals, Juan Francisco Gibaja, Olga Gómez, María Pilar Iborra, María Dolores López, Nekane Marín, Consuelo Mata, Ignacio Montero, Teresa Orozco, Josep Lluís Pascual, Guillermo Pascual, Consuelo Roca de Togores, Salvador Rovira, José Miguel Ruiz, Domingo Carlos Salazar, Maria Eulalia Subirà and Jaime Vives-Ferrándiz) for their help and support on this project. The autors would like to thank Maria Ntinou and Gilbert Marshall for translating the paper.

This work was supported by the research project of government of Spain HAR200914360-C03-01: "Análisis comparativo de las dinámicas socioeconómicas en la Prehistoria reciente peninsular (VI-II milenios AC): la fachada mediterránea".

\section{BIBLIOGRAPHY}

Andrés M. T.; García, M. L. and Sesma, J. 2001: "El sepulcro campaniforme de Tres Montes (Bárdenas Reales, Navarra). Intervención de urgencia de 1991 y campañas de 1996 y 1997”. Trabajos de Arqueología Navarra 15: 315-322.

Trab. Prehist., 70, N. ${ }^{\circ}$ 2, julio-diciembre 2013, pp. 264-277, ISSN: 0082-5638

doi: $10.3989 /$ tp. 2013.12112 
Barton, C. M.; Bernabeu, J.; Aura, J. E.; García Puchol, O.; Schmich, S. and Molina, Ll. 2004: "Long-term socioecology and contingent landscapes". Journal of Archaeological Method and Theory 11: 523-595.

Barton, C. M.; Ullah, I. I. and Bergin, S. 2010: "Land use, water and Mediterranean landscapes: modeling long-term dynamics of complex socio-ecological systems". Philosophical Transactions of the Royal Society A: Mathematical, Physical and Engineering Sciences 368 (1931): 5275-5297.

Bernabeu, J. 1984: El vaso campaniforme en el País Valenciano. Serie de Trabajos Varios 80, Servicio de Investigación Prehistórica, Diputación de Valencia. Valencia.

Bernabeu, J. 2010: "El mundo funerario entre el VI y el II milenio A.C.”. In A. Pérez and B. Soler (eds.): Restos de vida, restos de muerte. Museu de Prehistòria de València, Diputación de Valencia. Valencia: 45-54.

Bernabeu, J. and Molina, Ll. 2009: "La Cova de les Cendres. Valoración final". In J. Bernabeu and Ll. Molina (eds.): La Cova de les Cendres (MorairaTeulada, Alicante). Serie Mayor 6, Museo Arqueológico Provincial de Alicante, Diputación Provincial de Alicante. Alicante: 195-208.

Bernabeu Aubán, J.; Molina, L.; Orozco, T. and Díez, A. 2006: "Three millennia of Prehistory in Mediterranean Spain (5600-2000 cal BC)". In P. Díaz del Río and L. García Sanjuán (ed.): Social inequality in Iberian Late Prehistory. British Archaeological Reports, International Series 1525, Archaeopress. Oxford: 97-116.

Bernabeu, J.; Moreno, A. and Barton, C. M. 2012: "Complex systems, social networks and the evolution of social complexity”. In M. Cruz Berrocal, L. García Sanjuán and A. Gilman (eds.): The Prehistory of Iberia Debating Early Social Stratification and the State. Routledge. London: 23-37.

Blasco, A.; Edo, M. and Villalba, M. J. 2011: La cova de Can Sadurní i la Prehistòria de Garraf. Actes de les Jornades internacionals de Prehistòria 'El Garraf, 30 anys d'investigació arqueològica'. EDAR Arqueología y Patrimonio, Hugony editore. Milán.

Brodie, N. 1997: "New perspectives on the Bell Beaker Culture". Oxford Journal of Archaeology 16 (3): 297-314.

Bronk Ramsey, C. 2009: "Bayesian analysis of radiocarbon dates". Radiocarbon 51 (1): 337-360.

Bueno, P.; Barroso, R. and Balbín, R. 2005: "Ritual campaniforme, ritual colectivo: la necrópolis de cuevas artificiales del Valle de las Higueras, Huescas, Toledo". Trabajos de Prehistoria 62 (2): 67-90.

Castillo, A. del 1928: La cultura del vaso campaniforme. Su origen y extensión en Europa. Universidad de Barcelona. Barcelona.

Cámara, J.A.; Lizcano, R.; Pérez, C. and Gómez del Toro, E. 2008: "Apropiación, sacrificio, consumo y exhibición de los animales en el polideportivo de Martos. Sus implicaciones en los orígenes de la desigualdad social". Cuadernos de Prehistoria y Arqueología de la Universidad de Granada 18: 55-90.

Cámara, J. A. and Molina, F. 2006: "Selection of data, determinism and scientific relevance in interpretations of social development in the Late Prehistory of the Iberian Southeast". In P. Díaz del Río and L. García Sanjuán (eds.): Social inequality in Iberian Late Prehistory. British Archaeological Reports, International Series 1525, Archaeopress. Oxford: 38-58.

Case, H. J. 1995: "Beakers: loosening a stereotype". En I. Kinnes y G. Vamdell (eds.): Unbaked Ums of Rudely Shape. Oxbow Monographs 55. Oxford: 55-67.

Chapman, R. 2008: "Producing inequalities: Regional Sequences in Later Prehistoric Southern Spain”. Journal of World Prehistory 21 (3-4): 199-260.

Clarke, D. 1976: "The Beaker network-social and economic models". In J. N. Lanting and J. D. van der Waals (comps.): Glockenbecher Symposium (Oberried 1974). Fibula-van Dishoeck, Bussum/Haarlem: 459-477.

Clop, X. 2005: “La cuestión campaniforme en el Noreste de la Península Ibérica". In M. Rojo Guerra, R. Garrido-Pena and I. García Martínez de Lagrán (eds.): El campaniforme en la Península Ibérica y su contexto europeo/Bell Beakers in the Iberian Peninsula and their European context. Serie Arte y Arqueología 21, Universidad de Valladolid. Valladolid: 297-310.

Diez Castillo, A. 2011: "El marco cronológico a partir de la evidencia radiocarbónica del yacimiento de La Vital". In G. Pérez, J. Bernabeu, Y. Carrión, O. García, L1. Molina and M. Gómez (eds.): La Vital (Gandia, Valencia). Vida y muerte en la desembocadura del Serpis durante el III y el I milenio A.C. Serie de Trabajos Varios del Servicio de Investigaciones Prehistóricas 113, Diputació de Valencia. Valencia: 235-245.

Flors, E. 2009: Torre La Sal (Ribera de Cabanes, Castellón). Evolución del paisaje antrópico desde la prehistoria hasta el medioevo. Monografies de Prehistòria i Arqueologia Castellonenques 8, Servei d'Investigacions Arqueologiques i Prehisòriques, Diputació de Castelló. Castellón.

García Borja, P.; Salazar-García, D. C.; Pérez Fernández, A.; Pardo Gordo, S. and Casanova Vañó, V. 2011: "El Neolítico antiguo cardial y la Cova de la Sarsa (Bocairent, València). Nuevas perspectiva a partir de su registro funerario". Munibe 62: 175-195.

García Gazólaz, J. 2007: "Los enterramientos neolíticos del yacimiento de Paternanbidea (Ibero)". In La Tierra te sea leve. Arqueología de la muerte en Navarra. Catálogo de la exposición, Gobierno de Navarra [Pamplona]: 59-65.

García Gazólaz, J. and Sesma, J. 2007: “Enterramientos en el poblado neolítico de Los Cascajos (Los Arcos, 
Navarra)". In La Tierra te sea leve. Arqueología de la muerte en Navarra. Catálogo de la exposición, Gobierno de Navarra[Pamplona]: 52-58.

García Puchol, O. and Aura, J. E. 2006: El Abric de la Falguera (Alcoi, Alacant). 8.000 años de ocupación humana en la cabecera del río de Alcoi. Museo Arqueológico de Alicante, Diputación Provincial de Alicante.

García Puchol, O.; Molina Balaguer, Ll.; Aura Tortosa, J. E. and Bernabeu Aubán, J. 2009: "From the Mesolithic to the Neolithic on the Mediterranean coast of the Iberian Peninsula". Global Action in Human Context. Adapting to the Holocene in Iberia. Journal of Anthropological Research, special issue: 237-251.

Garrido Pena, R. 2005: "El campaniforme en la Península Ibérica y su contexto europeo". In M. Rojo Guerra, R. Garrido-Pena and I. García Martínez de Lagrán (eds.): El campaniforme en la Península Ibérica y su contexto europeo/Bell Beakers in the Iberian Peninsula and their European context. Serie Arte y Arqueología 21, Universidad de Valladolid. Valladolid: 29-60.

Garrido Pena, R.; Rojo, M. and García-Martínez de Lagrán, I. 2005: "Bell Beakers in Central Iberia (the inner Iberia)". In M. Rojo Guerra, R. GarridoPena and I. García Martínez de Lagrán (eds.): $E l$ campaniforme en la Península Ibérica y su contexto europeo/Bell Beakers in the Iberian Peninsula and their European context. Serie Arte y Arqueología 21, Universidad de Valladolid. Valladolid: 473-479.

Gibaja, F. F.; Majó, T.; Chambon, Ph.; Ruiz, J. and Subirà, E. 2010: "Las prácticas funerarias durante el Neolítico. Los enterramientos infantiles en el noreste de la Península Ibérica”. Complutum 21 (2): 47-68.

Gómez Puche, M.; Pérez Jordà, G. and Carrión Marco, Y. 2011: "El Espacio de la ocupación prehistórica". In G. Pérez, J. Bernabeu, Y. Carrión, O. García, Ll. Molina and M. Gómez (eds.): La Vital (Gandía, Valencia). Vida y muerte en la desembocadura del Serpis durante el III y el I milenio A.C. Serie de Trabajos Varios del Servicio de Investigaciones Prehistóricas 113, Diputació de Valencia. Valencia: 53-82.

Guilaine, J. and Zammit, J. 2001: Le sentier de la guerre. Visages de la violence préhistorique. Éditions du Seuil. Paris.

Harrison, R. J. 1977: The Bell Beaker Cultures of Spain and Portugal. American School of Prehistoric Research Bulletin 3, Peabody Museum. CambridgeMassachussets.

Healy, F. and Harding J. 2004: "Reading a burial: the legacy of Overton Hill". In A. Gibson and A. Sheridan (eds.): From Sickles to Circles: Britain and Ireland at the time of Stonehenge. Tempus. Stroud: 176-193.

Hurtado, V. 2008: "Ídolos, estilos y territorios de los primeros campesinos en el sur peninsular". In C.
Cacho, R. Maicas, J. A. Martos and M. I. Martínez Navarrete (eds.): Acercándonos al pasado. Prehistoria en 4 actos. Ministerio de Cultura, Museo Arqueológico Nacional y CSIC. http://man.mcu.es/museo/ JornadasSeminarios/ acercándonos_al_pasado.html (consulta 2-XI-2012).

Juan Cabanilles, J. 2005: "Las manifestaciones del Campaniforme en el País Valenciano. Una visión sintética”. In M. Rojo Guerra, R. Garrido-Pena and I. García Martínez de Lagrán (eds.): El campaniforme en la Península Ibérica y su contexto europeo/Bell Beakers in the Iberian Peninsula and their European context. Serie Arte y Arqueología 21, Universidad de Valladolid. Valladolid: 389-399.

Juan Cabanilles, J. 2009: El utillaje de piedra tallada en la Prehistoria reciente valenciana. Aspectos tipológicos, estilísticos y evolutivos. Serie de Trabajos Varios del Servicio de Investigaciones Prehistóricas 109, Diputación de Valencia. Valencia.

Lemercier, O. 2011: "Le guerrier dans l'Europe du IIIe millénaire av. n. è. L'arc et le poignard dans les sépultures individuelles campaniformes". In L. Baray, M. Honegger and M. H. Dias-Meirinho (eds.): L'armement et l'image du guerrier dans les sociétés anciennes. De l'objet à la tombe. Collection Art, Archéologie et Patrimoine, Editions Universitaires de Dijon. Dijon: 121-165.

Liesau, C.; Blasco, C.; Ríos, P.; Vega, J.; Menduiña, R.; Blanco, J. F.; Baena, J.; Herrera, T.; Petri, A. and Gómez, J. L. 2008: "Un espacio compartido por vivos y por muertos: el poblado calcolítico de fosos de Camino de las Yeseras (San Fernando de Henares, Madrid)". Complutum 19 (1): 97-120.

López Padilla, J. A. 2006: "Consideraciones en torno al 'Horizonte Campaniforme de Transición"'. Archivo de Prehistoria Levantina XXVI: 193-243.

Márquez Romero, J. E. 2004: "Muerte ubícua: sobre deposiciones de esqueletos humanos en zanjas y pozos en la Prehistoria reciente de Andalucía”. Mainake XXVI: 115-128.

McClure, S. B.; García, O.; Roca de Togores, C.; Culleton, B. and Kennett, D. 2011: "Osteological and paleodietary investigation of burials from Cova de la Pastora, Alicante, Spain". Journal of Archaeological Science 38 (2): 420-428.

Molina, Ll. and Clop, X. 2011: "La cerámica". In G. Pérez, J. Bernabeu, Y. Carrión, O. García, Ll. Molina and M. Gómez (eds.): La Vital (Gandia, Valencia). Vida y muerte en la desembocadura del Serpis durante el III y el I milenio A.C. Serie de Trabajos Varios del Servicio de Investigaciones Prehistóricas 113, Diputació de Valencia. Valencia: 183-201.

Molina, Ll. and Orozco, T. 2011: "Producción, consumo e intercambio en el registro material de la Vital". In G. Pérez, J. Bernabeu, Y. Carrión, O. García, Ll. Molina and M. Gómez (eds.): La Vital (Gandía, Valencia). Vida y muerte en la desembocadura del Serpis durante el III y el I milenio A.C.

Trab. Prehist., 70, N. ${ }^{\circ}$ 2, julio-diciembre 2013, pp. 264-277, ISSN: 0082-5638

doi: $10.3989 /$ tp. 2013.12112 
Serie de Trabajos Varios del Servicio de Investigaciones Prehistóricas 113, Diputación de Valencia. Valencia: 255-263.

Nocete, F. 2001: Tercer milenio antes de nuestra era. Relaciones y contradicciones centro/periferia en el Valle del Guadalquivir. Edicions Bellaterra. Barcelona.

Nocete, F.; Lizcano, R.; Peramo, A. and Gómez E. 2010: "Emergence, collapse and continuity of the first political system in the Guadalquivir Basin from the fourth to the second millennium BC: The longterm sequece of Úbeda (Spain)". Journal of Anthropological Archaeology 29: 219-237.

Odriozola, C. P.; Linares-Catela, J. A. and Hurtado-Pérez, V. 2010: "Variscite source and source analysis: testing assumptions at Pico Centeno (Encinasola, Spain)". Jounal of Archaeological Science 37: 31463157.

Orozco Köhler, T. 2000: Aprovisionamiento e Intercambio. Análisis petrológico del utillaje pulimentado en la Prehistoria reciente del País Valenciano (España). British Archaeological Reports, International Series 867, Archaeolingua. Oxford.

Pascual Beneyto, J. 2010: "El Barranc de Beniteixir". In A. Pérez and B. Soler (eds.): Restos de vida, restos de muerte. Museu de Prehistòria de València, Diputación de Valencia. Valencia: 191-194.

Pascual Beneyto, J.; Barbéra, J. M.; López, L.; Cardona, J.; Rovira, S. and Pascual Benito, J. Ll. 2008: "L'alqueria de Sant Andreu (Gandía). Avanç sobre un assentament costaner de finals del Neolític". In M. S. Hernández, J. A. Soler and J. A. López Padilla (eds.): IV Congreso del Neolítico Peninsular (Alicante 2006): 58-69. Alicante.

Pérez Jordá, G.; Bernabeu, J.; Carrión, Y.; García, O.; Molina, Ll. and Gómez, M. (eds.) 2011: La Vital (Gandia, Valencia). Vida y muerte en la desembocadura del Serpis durante el III y el I milenio A.C. Serie de Trabajos Varios del Servicio de Investigación Prehistórica 113, Diputació de Valencia. Valencia.

Reimer, P. J.; Baillie, M. G. L.; Bard, E; Bayliss, A; Beck, J. W.; Blackwell, P. G.; Bronk Ramsey, C.; Buck, C. E.; Burr, G. S.; Edwards, R. L.; Friedrich, M.; Grootes, P. M.; Guilderson, T. P.; Hajdas, I; Heaton, T. J.; Hogg, A. G.; Hughen, K. A.; Kaiser, K. F.; Kromer, B; McCormac, F.G.; Manning, S. W.; Reimer, R. W.; Richards, D. A.; Southon, J. R.; Talamo, S.; Turney, C. S. M.; van der Plicht, J. and Weyhenmeyer, C. E. 2009: "IntCa109 and Marine09 Radiocarbon Age Calibration Curves, 0-50,000 Years cal BP”. Radiocarbon 51: 1111-1150.

Roca de Togores, C. 2011: "Estudio antropológico y paleopatológico de los enterramientos calcolíticos". In G. Pérez, J. Bernabeu, Y. Carrión, O. García, Ll. Molina and M. Gómez (eds.): La Vital (Gandia, Valencia). Vida y muerte en la desembocadura del Ser- pis durante el III y el I milenio A.C. Serie de Trabajos Varios del Servicio de Investigaciones Prehistóricas 113, Diputació de Valencia. Valencia: 151-157.

Rovira, S. and Montero, I. 2011: "Aspectos metalúrgicos". In G. Pérez, J. Bernabeu, Y. Carrrión, O. García, Ll. Molina and M. Gómez (eds.): La Vital (Gandía, Valencia). Vida y muerte en la desembocadura del Serpis durante el III y el I milenio A.C. Serie de Trabajos Varios del Servicio de Investigaciones Prehistóricas 113, Diputación de Valencia. Valencia: 219-227.

Salanova, L. 2005: "The origins of the Bell Beaker phenomenon: Breakdown, analysis, mapping". In M. Rojo Guerra, R. Garrido-Pena and I. García Martínez de Lagrán (eds.): El campaniforme en la Península Ibérica y su contexto europeo/Bell Beakers in the Iberian Peninsula and their European context. Serie Arte y Arqueología 21, Universidad de Valladolid. Valladolid: 29-60.

Schuhmacher, T. X; Cardoso, J. L. and Banerjee, A. 2009: "Sourcing African ivory in Chalcolithic Portugal". Antiquity 83, 322: 983-997.

Sherratt, A. G. 1987: "Cups that Cheered". In W. H. Waldren and R. C. Kennard (eds.): Bell Beakers of the Western Mediterranean. Definition, interpretation, theory and new site data: The Oxford International Conference 1986. British Archaelogical Reports, International Series 331, Archaeopress. Oxford: 81-114.

Soler Díaz, J. A. 2002: Cuevas de inhumación múltiple en la Comunidad Valenciana. Real Academia de la Historia, Museo Arqueológico Provincial de Alicante. Madrid, Alicante.

Thomas, J. 2005: "Ceremonies of the Horseman? From megalithic tombs to Beaker burials in Prehistoric Europe". En M. Rojo Guerra, R. Garrido-Pena and I. García Martínez de Lagrán, I. (eds.): El campaniforme en la Península Ibérica y su contexto europeo/Bell Beakers in the Iberian Peninsula and their European context. Serie Arte y Arqueología 21, Universidad de Valladolid. Valladolid: 123-135.

Torregrosa Jiménez, P. and López Seguí, E. 2004: La Cova de Sant Martí (Agost, Alicante). Serie Memorias de Excavaciones arqueológicas 3. Museu Arqueològic d'Alacant. Alicante.

Utrilla, P.; Lorenzo, J. I.; Baldellou, V.; Sopena, M. C. and Ayuso, P. 2008: "Enterramiento masculino en fosa, cubierto de cantos rodados, en el Neolítico antiguo de la Cueva de Chaves". In M. S. Hernández, J. A. Soler and J. A. López Padilla (eds.): $I V$ Congreso del Neolitico Peninsular (Alicante 2006) 2: 131- 140. Alicante.

Zilhão, J. 1992: Gruta do Caldeirão. O Neolitico Antiguo. Trabalhos de arqueología 6, Instituto Portugués do Património Arquitectónico e Arqueológico. Lisboa. 